\title{
Effect of Mind Mapping as a Learning Tool on Online Learning of Chemistry
}

\author{
G A Nyagblormase ${ }^{1}$, A O Gyampoh ${ }^{1}$, J Hinson ${ }^{2}$, B Aidoo $^{3}$, E Yeboah ${ }^{4}$ \\ 1Science Department, Kibi Presbyterian College of Education (Ghana) \\ 2Science Department, Holy Child College of Education - Takoradi (Ghana) \\ 3School of Education, University of Iceland (Iceland) \\ 4Science Department, Mount Mary College of Education - Somanya (Ghana)
}

\begin{abstract}
Article Info
Article history:

Received August 18, 2021

Revised September 17, 2021

Accepted September 19, 2021

Available Online September 19, 2021

Keywords:

Covid-19

Graphic organizer

In-class learning

Online learning

Tutors

ABSTRACT

The advent of the Covid-19 pandemic brought distortions in the academic calendar of nations when educational institutions were closed. As a way of filling the gap created in the trend, tertiary institutions introduced online learning to support students' learning while at home. There was also the need to introduce alternative learning approaches to students that will help them summarize and represent the lengthy lecture notes and reading materials into meaningful and memorable units. This study looks at the effectiveness of mind maps in promoting this home-based online learning. The participants were seventy-one (71) first-year Bachelor of Education students pursuing a 4-year degree program in Basic Education in Kibi Presbyterian College of Education. One group consists of students pursuing Home Economics as their major and the other primary education. A test and questionnaire were used to collect data. T-test was used to test the significance of the performance of the two groups, and multiple regression was used to find an association between the use of the strategy and students' performance. The statistical software used for data analysis was IBM's SPSS version 25. The result shows that the mind map strategy helped learners retain knowledge; however, students' understanding of concepts was low.
\end{abstract}

\section{INTRODUCTION}

The need for online learning, synchronous or asynchronous, arose globally and in Ghana due to Covid -19 pandemic. The pandemic set in when tertiary institutions in Ghana were to resume for the second semester of teaching and learning activities. The sudden change from in-class learning to online learning came as a challenge to both teachers and learners, as the country's educational system, until then, placed little or no emphasis on online education.

It was a challenge for tutors in Colleges of Education because most of them had little knowledge in Information and Communication Technology (ICT) and had no background on online lesson planning and teaching strategies. More complicated was the lack of knowledge of teachers on the use of online teaching tools and software. In a study to assess the preparedness of tutors of Colleges of Education for online teaching in the Covid-19 period, Gyampoh et al. (2020) found that only $33.3 \%$ of tutors interviewed could teach confidently online, while $66.7 \%$ need further training to deliver lessons online confidently. For online learning to be successful, tutors must invest more time in intensive preparations such as lesson plan preparation to meet online needs and technical abilities to encode and upload learning materials. 
Students equally have their challenges. Most of them stayed in remote villages where mobile networks are not available. Even though they are students in tertiary institutions, most do not have modern communication gadgets like smartphones and laptops that could help them access their learning notes and other information on the internet. Financial constraints prevented most learners from acquiring data to access information posted on their various learning portals. These challenges are embedded in the list of five common challenges of online learning enumerated by Kumar (2015): adaptability, technical issues, computer literacy, time management, and self-motivation. Again, Kumar (2015) opined that the sudden transition from classroom face-to-face instruction to online learning posed problems to the students who had the traditional mindset.

The second semester commenced amid all these challenges, and both tutors and students in Colleges of Education were expected to start teaching and learning of the semester's courses online. Despite the shortcomings of teachers as far as communication technology is concerned, teaching and learning must continue. Teachers had to adopt creative teaching strategies to help learners to learn the content of courses with ease. According to Rankin and Brown (2015), innovative learning strategies promote meaningful learning, student engagement, and peer interaction.

One significant component of online learning is that the learners must take responsibility for their learning. Online learning is likened to adult-based knowledge in which the learners must take charge and own their learning, mostly learning independently in a holistic manner. That is, it is self-directed learning, and this implies that the success of a student in an online course depends on the learning effort put in by the learner. The challenge for the instructor is how to design appropriate instructional approaches to increase student activity and student responsibility concerning their own learning. Another role of the teacher is to provide the necessary course materials and guidance to the learner.

Based on these challenges, the researchers examined Mind Map learning strategy on students' learning of Pure and Impure substances, a concept that is part of their secondsemester chemistry course for level 100 students in Home Economics and Primary Education majors. The research examines how effective the Mind Map learning strategy will promote students' retention of knowledge, understanding of concepts, and procedural knowledge in the concept. There had been several publications on online learning, but few studies have highlighted the use of mind maps as a learning tool in chemistry among pre-service graduate teachers in Colleges of Education in Ghana. The researchers believed this study would add knowledge to teaching and learning strategies adopted by College of Education tutors in this Covid-19 period.

\section{Purpose of the study}

This study aimed to compare the effectiveness of the mind map learning strategy to the traditional lecture method in online learning to promote understanding of chemistry concepts. The concept covered was Pure and Impure substances, which includes compounds and mixtures and separation or purification techniques.

\section{LITERATURE REVIEW}

According to Meister (n.d.), a mind map is a visual display of information in the form of a diagram. It is a "visual tool used to organize information," take notes and summarize concepts (Jiang, 2020). The open-flowing format of mind mapping supports the natural thinking process (Wilson et al., 2016) and makes it a suitable representation style. D' Antoni et al. (2010) describe mind maps as multi-sensory tools that may help medical students organize, integrate, and retain information.

The mind map is a useful teaching and learning technique that helps learners to learn more effectively. It can improve learners' mode of recording information, support, and enhance their ability to solve a problem creatively. As a graphic organizer, mind maps summarize 
information in a format that the mind finds easy to recall (Adodo, 2013) hence supports remembrance. It makes lengthy conventional notes more compact and helps making associations and generalizations easier.

The mind map is a kind of graphic organizer that teachers employ to summarize concepts. Graphic organizers are visual illustrations of ideas, information, and verbal statements. The theme or concept, or subject of a mind map, is centrally located, from which sub-concepts radiate.

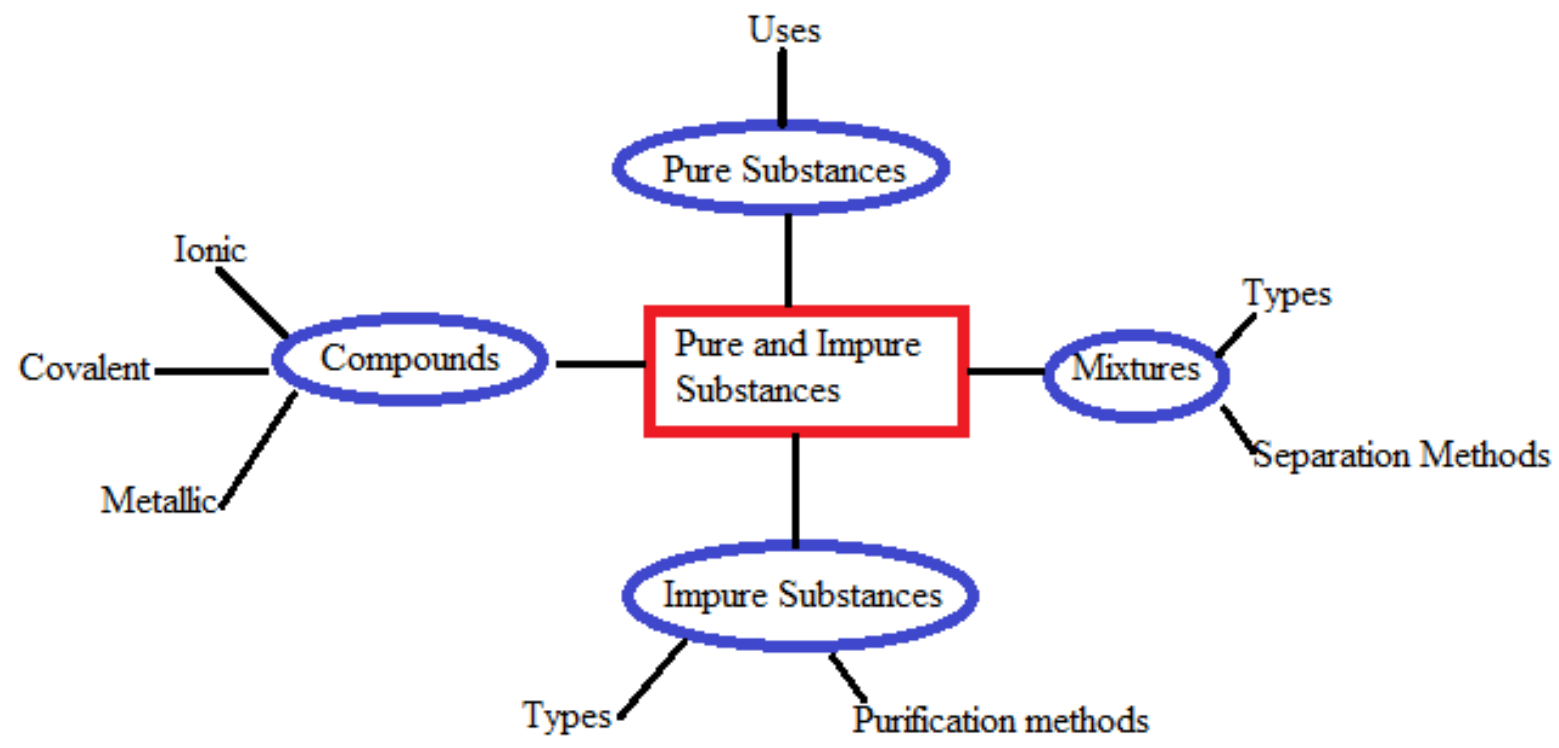

Figure 1. Sample mind map adapted from Researchers (2021)

In Chemistry, mind maps help teach inquiry process skills in defining features, charts, and diagrams. Chemistry teachers can use them as instructional strategies to record observed information or from reading to create a descriptive model of phenomena. According to Brinkmann (2003), visual appeal can boost memorization and recall, which is expected to speed up the learning process.

Employing the mind map technique in lesson delivery makes students learn a sensemaking process (Zhao, 2003), and it is an active learning technique. Ueckert and Gess-Newsome (2008) describe active learning techniques (short demonstrations, think-pair-share, group projects, case study, role-play, etc.) as processes that recognize individuals' engagement with the content of a lesson and with others. Active learning unveils initial ideas, makes connections between ideas, and helps to construct new knowledge from learners' experiences.

The researchers believe that mind mapping activities will promote a deeper level of approach to the learning process. More significant learning would also be achieved, based on Vekiri's (2002) research that visual displays play a vital role in the learning process. Students representing their knowledge in pictorial forms are helpful because they can self-regulate their learning since they will externalize their thoughts and compare them with the thinking of others. Spencer et al. (2013) found that mind maps are creative and unique learning methods in which students expand their memory and recall critical topics.

Researchers found that using mind map as a learning strategy improves students' grades in Chemistry (Abi-El-Mona \& Abd-El-Khalick, 2008), increases the achievement scores of students (Horton et al., 1993), and promotes retention of knowledge (Nesbit \& Adesope, 2006). Mind maps are instrumental in notetaking and arranging thought (Boyson, 2009), planning, and organizing information (Wilson et al., 2016). Meister (n.d.) argues that student's ability to create mind maps can lead to faster memorization of information, ease of writing essays, and the student's ability to create engaging presentations. 
Mind maps are helpful to instructors. Edwards and Cooper (2010) indicated that mind maps help the instructor prepare and review lectures, while Nesbit and Adesope (2006) found that when teachers use mind maps, it helps them vary their teaching methods, and diverse learners may benefit from this diversity. Mind maps affect forcing students to learn information since it enables them to organize information meaningful and add images and color to it. Nesbit and Adesope (2006) indicated that the use of mind maps lowers the extrinsic cognitive load. Chandler and Sweller (1991) described cognitive load as the working memory load experienced by learners as they interact with materials. Mind maps enhance students' learning by creating a visual image of the concept being learned (Budd, 2004). Mind maps improve the metacognitive skills of learners (Astriani et al., 2020) and permit students to make associations with material meaningfully. Budd (2004) indicated that mind maps are used as 'reflective tools' that enable the extended association to be made to materials.

In teaching Chemistry, Anil (2018) argues that mind maps can create wonders in learners' output. He indicated that mind maps could help learners gather and hold many data and encourage problem-solving because learners see new or novel pathways, increase retention, and make learners achieve higher levels of creativity, increased concentration, and clear organization of thought. Mind maps, to him, improve the mental ability of learners, help to remember names, facts, formulae, and figures, and make recall easy. Meister (n.d.) also listed the following advantages of mind maps:

- The radiant structure mind map resembles the way our brains store and process and retrieve information.

- Mind maps convey the relationships between individual ideas, so you see hierarchy and the entire concept in diagrams.

- Memorization is maximized as the colors, pictures, and connections the mind map use make things easier to recall.

\section{THEORETICAL FRAMEWORK}

Mind mapping hinges on the constructivist approach or theory. Constructivism believes that people build their knowledge in their minds from what they do (Issman, 1999). When constructing information, the constructivist theory is concerned with the process, as Durmus (2001) found. Information depends on our knowledge of the subject matter, our experiences with the subject matter, how we arrange our experiences about the subject matter, and our beliefs about our experiences. The lens through which we view the world is established by our various experiences. Students and teachers do not have the same knowledge and experience, making the transfer of teachers' personal experiences incomplete. Mind mapping requires employing these tools, which provide a useful and long-lasting education (Bütüner, 2006).

\section{Research Questions}

Three research questions were formulated to guide this research, and one hypothesis was tested using a student's t-test.

1. What learning strategies do students use before and during the Covid-19 period?

2. What is students' perception about using the mind map learning approach to the learning of scientific concepts?

3. What is the effect of using the mind map learning approach in the online learning of chemistry?

$\mathrm{H}_{0}$ : there is no significant difference in students' performance using lecture and mind map learning strategies in online learning of chemistry.

$\mathrm{H}_{1}$ : there is a significant difference in students' performance using lecture and mind map learning strategies in online learning of chemistry. 


\section{METHODOLOGY}

\section{Research Design}

The study examines the effect of mind maps in online teaching on students' performance in the chemistry concepts of Pure and Impure Substances and Mole Concept. It employs the experimental versus control group design. Two intact levels 100 groups were purposively selected and randomly assigned to experimental and control groups. Forty students offering Home Economics as their major formed the Experimental group, while thirty-one (31) students offering Primary Education create the control group. The two groups were purposively selected because they provided General Chemistry as a core course for that semester. A simple ballot was conducted to assign the two groups into experimental and control groups. The experimental group was introduced to the mind map learning approach, while the conventional method was used on the control group.

\section{Participants}

The participants in this study are first-year Bachelor of Education students pursuing a 4-year degree program in Basic Education in Kibi Presbyterian College of Education. One group consists of students pursuing Home Economics as their major and the other primary education. The chemistry course mounted for the two groups for the semester was General Chemistry. The General Chemistry course was designed to consolidate and expand the content, and skills students have acquired from their lessons in Integrated Chemistry at the senior high school level, particularly topics in chemistry. It also reflects some of the issues treated at the primary school level and the senior high school. To the Home Economics students, the General Chemistry course is to increase their knowledge in the chemistry of food and related ideas. The Home Economics group comprises 40 students - 36 females and 4 males, while the Primary Education group includes 31 students consisting of 18 females and 13 males.

\section{Mind mapping activities}

As a result of the Covid -19 pandemic, lesson delivery, and learning have changed from face-toface to online. In Kibi Presbyterian College of Education, Google Classroom and Moodle were used for asynchronous lessons, while Zoom, Telegram, and WhatsApp were used for synchronous lessons. The tutors use multiple platforms to deliver their lessons because students who miss the synchronous sessions can access the asynchronous platforms. As the weeks unfolded, the researchers realized that the number of students who accessed the Zoom sessions declined and never exceeded a quarter of the entire class. The number of students who visited the Google Classroom to assess the lessons posted there was better than the synchronous attendance.

The researchers then thought of a learning strategy that would help learners summarize lessons posted on the asynchronous platform in the forms of PowerPoint, videos, and write-ups in diagrammatic forms that would aid lesson assimilation and memory. A lesson on using a mind map as a learning strategy was posted on the Google Classroom platform for students in the Home Economics major group to study. They were also invited to a synchronous session on zoom and were taken using a mind map as a learning strategy. The researchers, having been assured that the students understood using mind maps as a learning strategy, posted two lessons on the google platform for the learners to study. The lessons were on the mole concept and pure and impure substances. The students were told to explore the ideas and draw mind maps on the two pictures. This exercise they submitted in person to the course tutors for assessment.

However, the Primary Education major group was not taken through the mind mapping activities but were taken through the lessons presented in the synchronous and asynchronous forms. When the Covid-19 pandemic subsided a bit, the students returned to college for four weeks face-to-face. Two weeks were used for revision and two weeks for examination. Within the revision week, the researchers gave an eight-item test to both the Primary Education major 
group and the Home Economics group to determine the effect of the mind mapping activities on the experimental group. The researchers wanted to determine whether the mind-mapping activities could enhance or improve learners' knowledge, concepts, and procedural knowledge. Also, the experimental group was given a questionnaire to examine their experience with the mind mapping learning strategy.

\section{Instrumentation and Data collection}

The researchers used two tools to collect data for the study. These include tests and questionnaires. The test was made up of eight items. Items 1-4 were designed to test students' recall of knowledge. Items 5 and 6 were designed to test students' understanding of the concepts under study, while items 7 and 8 were designed to test students' procedural knowledge in terms of mole calculations. In scoring the tests, the researchers used two scoring approaches. In one method, the marks scored in the knowledge, understanding, and procedural domains were scored on a 4-point Likert scale (very adequate, adequate, fair, and inadequate. All the points in all 8 items were summed up to give the student's total score in the other approach. An 18-item questionnaire was used to examine students' perceptions about using the mind map learning approach. The questionnaire was administered to the Home Economics group only because they were taken through the mind map learning approach. Three of the items were open-ended, while the rest were graded on a 4-point Likert scale.

To ensure the credibility and reliability of the test items and the questionnaire, the items were submitted to the research committee of the Chemistry department and the college assessment unit for review. Their recommendations and suggestions helped to reshape the items before they were given to the student. Due to the limited time, the students had to spend on campus and their preparation for the end-of-semester examinations, the items were not pilot tested.

The data collected were analyzed using version 27 of IBM SPSS software. The statistics calculated are frequencies and paired sample t-test.

Data Presentation and analysis

Learning approaches students used before and during the Covid-19 period.

Table 1: Learning strategy conversant with

\begin{tabular}{ccc}
\hline & $\mathrm{N}$ & $\%$ \\
\hline Self study & 12 & 30.8 \\
Diamond line conversant & 1 & 2.6 \\
Concept map & 4 & 10.3 \\
Mind map & 3 & 7.7 \\
Group study & 18 & 46.2 \\
Other & 1 & 2.6 \\
\hline
\end{tabular}

Whether at home or in school, students must continue learning. There are many learning approaches, and individuals have their preferred strategies. Data on learners' learning approaches before the pandemic shows a significant preference for group study and self-study. A few students used a concept map, while two students mention diamond nine. The responses showed that $59 \%$ of the students used at least one learning strategy, 5.1\% used at least two strategies, and $15.4 \%$ used three strategies. $10.3 \%$ used four or more strategies, while $10.3 \%$ used none, indicating that some students were not concerned about learning while out of school.

During the Covid-19 lockdown, all the students mentioned self-study using online resources like U-tube videos and online texts, using search engines like Google, Yahoo, and Vidmate. Their responses showed that many of the students were willing to take responsibility for their learning in the instructor's absence. 
Table 2: Descriptive statistics of different learning styles

\begin{tabular}{lccccc}
\hline & $\mathrm{N}$ & Mean & SD & Min. & Max. \\
\hline Self study & 11 & 8.36 & 3.53 & 3 & 13 \\
Group study & 26 & 9.19 & 3.07 & 1 & 14 \\
Self and group study & 11 & 10.45 & 3.75 & 5 & 15 \\
Multiple & 23 & 10.57 & 3.64 & 2 & 18 \\
\hline
\end{tabular}

The descriptive statistics of the various learning styles are shown in Table 2. As indicated, the means for learning styles factors were not different from each other.

A one-way independent-samples of variances (ANOVA) was conducted to investigate the impact of different learning styles on student's achievement. There was a significant effect of different learning styles on exam performance, $\mathrm{F}(2,37)=.36, p>.001, \mathrm{n}_{\mathrm{p}}{ }^{2}=.02$. Bonferroni posthoc comparisons revealed that those who used self-study only and group study and self-study $(\mathrm{M}=8.36, \mathrm{SD}=3.53)$ were lower but statistically insignificant $(\mathrm{M}=8.00, \mathrm{SD}=3.23)$, students who used group study only and self and group study $(\mathrm{M}=9.19, \mathrm{SD}=3.07)$ were lower but statistically insignificant $(\mathrm{M}=8.00, \mathrm{SD}=4.36)$.

Table 3: Students' perception about the use of mind map learning strategy

\begin{tabular}{|c|c|c|c|c|}
\hline \multirow{2}{*}{ Variable } & \multicolumn{2}{|c|}{ Percentage (\%) } & \multirow{2}{*}{ Mean } & \multirow{2}{*}{ SD } \\
\hline & Agree & Disagree & & \\
\hline I understand the mind mapping learning strategy & 65.0 & 32.0 & 2.08 & 1.12 \\
\hline Mind mapping is relevant learning strategy & 83.8 & 16.2 & 1.68 & 0.82 \\
\hline I can summarize lengthy lessons with mind mapping & 71.8 & 28.2 & 1.97 & 0.96 \\
\hline It has decreased the time spent on learning concept & 65.7 & 34.3 & 1.97 & 0.99 \\
\hline Easily recall concepts with mind map diagrams & 73.0 & 27.0 & 2.03 & 0.93 \\
\hline Can confidently draw mind map concepts in any subject & 70.3 & 29.7 & 2.08 & 1.04 \\
\hline My recall and memorization power has boosted & 67.6 & 32.4 & 2.08 & 1.12 \\
\hline I can make connections between ideas and concepts & 78.9 & 21.1 & 1.74 & 0.98 \\
\hline I can explain scientific concepts to friends & 76.3 & 23.7 & 1.95 & 1.09 \\
\hline I can perform better in tests with a mind map & 73.0 & 27.0 & 2.03 & 1.09 \\
\hline The mind map has stimulated my interest in Chemistry & 65.8 & 34.2 & 2.21 & 1.14 \\
\hline I can use my mind up to ideas for knowledge transfer & 73.7 & 26.3 & 1.89 & 1.13 \\
\hline Drawing a mind map on concepts wastes time & 63.2 & 36.8 & 2.97 & 0.94 \\
\hline I can use other graphic organizers than mind map & 55.9 & 44.1 & 2.50 & 0.86 \\
\hline
\end{tabular}

Table 3 shows the responses to the questionnaire assessing students' perceptions about using the mind map learning approach. A good number of the respondents agree with the advantages of the use of a mind map; that is, it can be used to summarize lengthy lessons $(83.8 \%)$, recall concepts $(73.0)$, boost memorization of concepts $(67.6 \%)$, and see connections between ideas. However, most of them admitted that mind map is difficult to draw $(64.1 \%)$, and it wastes their time $(63.2 \%)$, but agreed that they would perform well when they are tested on concepts, they learn using mind maps $(73.0 \%)$. The researchers then conclude that a mind map is a good learning strategy for online learning. It will help the learners to organize concepts in meaningful ways.

\section{Effect of the use of mind map learning approach in the online learning of chemistry}

The effect of using mind map learning approach on student's academic performance was analyzed using an independent $t$-test. The t-test was conducted to explore the differences in means performance between the experimental group and control group. An alpha level of 0.5 was utilized. Descriptive statistics are shown in table 3. Homogeneity of variance was conducted using Levene's test with all the groups were normally distributed and variations were homogenous, $\mathrm{F}(1,32)=.506, p>.05$, hence equal variances were assumed. 
Table 4. Independent Samples t-test for control and experimental group scores

\section{Levene's Test for}
Equality of

Variances

\begin{tabular}{|c|c|c|c|c|c|c|c|c|c|c|c|}
\hline & \multirow[t]{2}{*}{ Mean } & \multirow[t]{2}{*}{$\mathrm{SD}$} & \multirow[t]{2}{*}{$\mathrm{F}$} & \multirow[t]{2}{*}{ Sig. } & \multirow[t]{2}{*}{$\mathrm{t}$} & \multirow[t]{2}{*}{$\mathrm{df}$} & \multirow[t]{2}{*}{$\begin{array}{l}\text { Sig. (2- } \\
\text { tailed) }\end{array}$} & \multirow[t]{2}{*}{$\begin{array}{l}\text { Mean } \\
\text { diff. }\end{array}$} & \multirow[t]{2}{*}{$\begin{array}{c}\text { Std. } \\
\text { Err diff }\end{array}$} & \multicolumn{2}{|c|}{$\begin{array}{c}95 \% \text { Confidence } \\
\text { Interval of the } \\
\text { Difference }\end{array}$} \\
\hline & & & & & & & & & & Lower & Upper \\
\hline Control & 7.81 & 3.06 & \multirow{2}{*}{.506} & \multirow{2}{*}{.482} & \multirow{2}{*}{-1.933} & \multirow{2}{*}{32} & \multirow{2}{*}{.062} & \multirow{2}{*}{-3.527} & \multirow{2}{*}{1.825} & \multirow{2}{*}{-7.244} & \multirow{2}{*}{.190} \\
\hline Experimental & 11.33 & 2.31 & & & & & & & & & \\
\hline
\end{tabular}

No statistically significant difference was found in the scores for the experimental group $(\mathrm{M}=11.33, \mathrm{SD}=2.31)$ and the control group $(\mathrm{M}=7.81 \mathrm{SD}=3.06)$ conditions; $\left.\mathrm{t}_{(32)}=-1.933, p>.05\right)$. A small effect was noted, $\mathrm{d}=0.13$, indicating a weak significance. This implies that using the mind map approach to online learning improved the learners' performance in the Home Economics group than that of the Primary Education group who used the conventional approach to learning. The researchers then conclude that the mind mapping learning strategy improves student's learning and performance.

Table 5: Comparison of students' performance in knowledge recall, concept understanding, and procedural knowledge.

\begin{tabular}{cccccccc}
\hline \multirow{2}{*}{ Variable } & \multicolumn{3}{c}{ Percentage $(\%)$} & \multirow{2}{*}{ Inadequate } & \multirow{2}{*}{ Mean } & \multirow{2}{*}{ SD } \\
\cline { 2 - 4 } & Adequate & Adequate & Fair & & & \\
\hline Knowledge recall & 15 & 38 & 25 & 2.5 & 2.55 & 1.011 \\
Understanding & 10 & 10 & 20 & 57.5 & 3.40 & 1.128 \\
Procedural knowledge & 33 & 25 & 30 & 12.5 & 2.23 & 1.050 \\
\hline
\end{tabular}

Students' score in the three cognitive domains was graded as very adequate $(\mathrm{VA}=5)$, adequate $(\mathrm{A}=4)$, fair (Fair $=2$ to 3 ) and inadequate ( $\mathrm{In}=0$ to 1 ). Table4 shows that $53 \%$ of students displayed good knowledge recall when using the mind mapping learning strategy, while $25 \%$ displayed fair recall of knowledge. In terms of knowledge recall, that of $23 \%$ of the students was inadequate. Only $20 \%$ of students performed well on concept understanding, and another $20 \%$ showed fair understanding. As many as $60 \%$ of the students showed an inadequate understanding of the scientific concepts. The researchers reasoned that student using mind maps in their studies only attempt to memorize the concept rather than pay attention to understanding the concepts. In the following procedures, the table indicated that $60 \%$ of students showed adequate knowledge in this area, while $30 \%$ showed adequate knowledge. However, the procedural knowledge of $13 \%$ of students was found to be inadequate; that is, $88 \%$ of students showed adequate knowledge in following procedures. The researchers, therefore, conclude that the use of mind map learning strategy in online learning of Chemistry, in this study, favors knowledge recall and procedural knowledge but limits understanding of concepts. 


\section{Performance of students in terms of gender}

Table 6: Independent samples t-test comparing males and females in knowledge recall, concept understanding, and procedural knowledge.

\begin{tabular}{llccc}
\hline Factors & Gender & $\mathrm{N}$ & Mean & $\mathrm{SD}$ \\
\hline \multirow{2}{*}{ Knowledge recall } & Male & 4 & 2.25 & 1.50 \\
\multirow{3}{*}{ Understanding concepts } & Female & 36 & 2.58 & 0.97 \\
& Male & 4 & 3.50 & 1.29 \\
\multirow{2}{*}{ Procedural knowledge } & Female & 36 & 3.39 & 1.13 \\
& Male & 4 & 2.00 & 1.16 \\
& Female & 36 & 2.25 & 1.05 \\
\hline
\end{tabular}

${ }^{*} \mathrm{p}<0.001$

Table 6 showed there were no significant differences between male and female students knowledge acquisition in terms of "recall" $(\mathrm{t}=-0.62, \mathrm{p}=.539)$, no significant differences in understanding in terms of gender $(t=0.19, p=.855)$, and there were no significant gender differences in terms of procedural in favor of female $(t=-0.45, p=.657)$.

\section{Students' perception of mind mapping}

Students expressed their personal views about the use of the mind map concept. Table 3 shows a few of the positive and negative opinions expressed by learners. Students' dispositions and ideas were vital on the use of mind maps for learning. Participants described their positive beliefs of being in mind map enacted learning environment. Their comments provide better information about mind mapping helped them to learn. Participants reported mind mapping helped them to recall knowledge from the concepts.

Shanty said "mind map increased my creativity and productivity because it is an excellent tool to generate more ideas. The mind map is not difficult to draw, and you can also use it on other subject areas.....It is a relevant strategy, and it has helped me a lot".

The participants also expressed mind mapping enhanced their understanding of concepts and transferred the knowledge in other areas.

According to Liza, mind map makes learning easy and fast, and many concepts are captured when using mind map......It helps you know all the areas of the topic.

The participants reported mind mapping is an effective instructional strategy in a chemistry classroom.

Agbe also opined that the mind map learning approach is an excellent approach to learning. It helps you easily recall concepts related to the topic...... it is ideal for personal studies, group studies, and online studies.......It is a good strategy because it does not waste time, and it helps you recall what you have learned.

Despite the benefits of the mind mapping approach, the participants reported having difficulty using it to learn.

According to Kofi, it is challenging to study when learning... I find it challenging to use it. It was very confusing the first time was introduced to it. 
Most students who used the mind map learning approach gave positive comments about it. The positive comments go to reinforce the findings of earlier researchers about the use of the approach.

\section{DISCUSSION AND CONCLUSION}

The study's findings showed that learners who used the mind map learning approach during the online learning period displayed improved performance than students who used the traditional method in learning. This finding supports earlier research on the effectiveness of the mind map strategy (Adodo, 2013; Abi-El-Mona \& Abd-El-Khalick, 2018; Astriani et al., 2020).

The research outcome shows a need for instructors to introduce learners to creative learning approaches that will help them learn and generate knowledge for themselves, especially online education. A mind map is one of the innovative approaches that instructors can adapt at all levels to help learners organize lessons and concepts in a meaningful way since the approach makes students' learning a sense-making process (Zhao, 2003) because it is an active learning technique (Ueckert \& Gess-Newsome, 2008).

The researchers were able to identify the misconceptions of learners in learners' knowledge and re-plan their lessons to correct the misconceptions. This aligns with Edwards and Cooper (2010), who said that mind maps help the instructor prepare and review lectures. Nesbit and Adesope (2006) also indicated that mind maps help instructors to vary their teaching methods, and diverse learners can benefit from this diversity. The researchers suggest that tutors at colleges of education adopt this strategy to help pre-service teachers improve their procedural, recall, and understanding of knowledge levels. Brinkmann (2003) found that the approach can boost memorization and recall, which is expected to speed up the learning process.

\section{ACKNOWLEDGEMENTS}

The authors acknowledge the unconditional support from all participants in this project. Again, this project received no grant.

\section{REFERENCES}

Abi-El-Mona, I., \& Abd-El-Khalick, F. (2008). The influence of mind mapping on eighth graders' chemistry achievement. School Chemistry and Mathematics, 108(7), 298-312.

Adodo, S. O. (2013). Effect of mind-mapping as a self-regulated learning strategy on students' achievement in Basic Chemistry and technology. Mediterranean Journal of Social Chemistry, 4(6) 163-172.

Anil. (2018). Effectiveness of mind mapping technique in teaching chemistry to secondary school students in relation to their academic achievement. International Journal of Scientific Research in Chemistry and Technology, 4(2), 76 - 83.

Astriani, D., Susilo, H., Suwono, H., \& Lukiati, B. (2020). Mind mapping in learning models: A tool to improve student metacognitive skills. International Journal of Emerging Technologies in Learning (iJET), 15(06). https:// doi.org/10.3991/ijet.v15i06.12657

Brinkmann, A. (2003). Graphical knowledge display-mind mapping and concept mapping as efficient tools in mathematics education. Mathematics Education Review, 16, 35-48.

Budd, J. W. (2004). Mind maps as classroom exercises. The Journal of Economic Education, 35(1). https://doi.org/10.3200/JECE.35.1.35-46

Bütüner, S. Ö. (2006). Açılar ve üçgenler konusunun ilköğretim 7. sını öğrencilerine ve diyagramları ve zihin haritaları kullanılarak öğretimi [Master's Thesis, Balıkesir Üniversitesi]. DSpace@Balıkesir Kurumsal Akademik Arşiv. http://dspace.balikesir.edu.tr/xmlui/handle/20.500.12462/1622

Chandler, P., \& Sweller, J. (1991). Cognitive load theory and the format of instruction. Cognition and Instruction, 8(4), 293-332. 
D'Antoni, A. V., Zipp, G. P., Olson, V. G., \& Cahill, T. F. (2010). Does the mind map learning strategy facilitate information retrieval and critical thinking in medical students?. BMC Med Educ, 10. https:// doi.org/10.1186/1472-6920-10-61

Durmuş, S. (2001). Matematik eğitimine oluşturmacı yaklaşımlar. Kuram ve Uygulamada Ĕgitim Bilimleri Dergisi, 1, 91-107.

Edwards, S., \& Cooper, N. (2010). Mind mapping as a teaching resource. The Clinical Teacher, $7(4), 236-239$.

Gyampoh, A. O., Ayitey, H. K., Fosu-Ayarkwah, C., Ntow, S. A., Akossah, J., Gavor, M., \& Vlachopoulos, D. (2020). Tutor perception on personal and institutional preparedness for online teaching-learning during the COVID-19 crisis: The case of Ghanaian Colleges of Education. African Educational Research Journal, 8(3), 511-518. https://doi.org/10.30918/AERJ.83.20.088

Horton, P. B., McConney, A. A., Gallo, M., Woods, A. L., Senn, G. J., \& Hamelin, D. (1993). An investigation of the effectiveness of concept mapping as an instructional tool. Chemistry Education, 77, 95-111.

Işman, A. (1999, March). Eğitim teknolojisinin kuramsal boyutu: Yapısalcı yaklaşımın (constractivisim) eğitim öğretim ortamına etkisi. Öğretmen Eğitiminde Çağdaş Yaklaşımlar Sempozyumu, Dokuz Eylül Üniversitesi, İzmir, Turkey.

Jiang, Y. (2020) Application of the mind map in learning English vocabulary. Open Access Library Journal, 7, 1-4. https://doi.org/10.4236/oalib.1106484

Kumar, S. (2015, July 10). 5 Common problems faced by students in e-learning and how to overcome them. eLearning Industry. https://elearningindustry.com/5-common-problems-faced-bystudents-in-elearning-overcome

Meister, R. B. (n.d.). 15 Creative mind map examples for students. Retrieved December 17, 2020, from https://www.mindmeister.com/blog/students-guide-to-mind-mapping/

Nesbit, J. C., \& Adesope, O. O. (2006). Learning with concept and knowledge maps: A metaanalysis. Review of Educational Research, 76(3), 413-448.

Network Support (201, April 18). Why use graphic organizers in the classroom. Professional Learning Board. https://k12teacherstaffdevelopment.com/tlb/why-use-graphicorganizers-in-the-classroom/

Sapitri, L., Rachmawati, E., \& Surachmat, A. M. (2019). The use of mind mapping technique to increase EFL students' motivation in writing (A case study at the eighth grade of a junior high school in Brebes) Journal of English Education and Teaching, 3(3), 392-402. https://doi.org/10.33369/jeet.3.3.392-402

Spencer, J. R., Anderson, K. M., \& Ellis, K. K. (2013). Radiant thinking and the use of the mind map in nurse practitioner education. The Journal of Nursing Education, 52(5), 291-293. https://doi.org/10.3928/01484834-20130328-03

Ueckert, C. W., \& Gess-Newsome, J. (2008). Active learning strategies: Three activities to increase student involvement in learning. The Chemistry Teacher, 75(9), 47-52.

Vekiri, I. (2002). What is the value of graphical displays in learning?. Educational Psychology Review, 14(3), 261-312. https://doi.org/10.1023/A:1016064429161

Wilson, K., Copeland-Solas, E., \& Guthrie-Dixon, N. (2016). A preliminary study on the use of mind mapping as a visual learning strategy in general education chemistry classes for Arabic speakers in the United Arab Emirates. Journal of the Scholarship of Teaching and Learning, 16, 31-52.

Zhao, Y. (2003). The use of a constructivist teaching model in Environmental Chemistry at Beijing Normal University. The China Papers, 2, 78-84.

Zipp, G. P. (2011, September 7). Using mind maps as a teaching and learning tool to promote student engagement. Faculty Focus. https://www.facultyfocus.com/articles/teaching-andlearning/using-mind-maps-as-a-teaching-and-learning-tool-to-promote-studentengagement/ 
Effect of Mind Mapping as a Learning Tool on Online Learning of Chemistry

Author (s):

George Agbenyega Nyagblormase

Science Department, Kibi Presbyterian College of Education (Ghana)

Email: agbenyegageorge50@gmail.com

*Alexander Obiri Gyampoh (Corresponding Author)

Science Department, Kibi Presbyterian College of Education (Ghana)

Email: ao.gyampoh@gmail.com

James Hinson

Science Department, Holy Child College of Education - Takoradi (Ghana)

Benjamin Aidoo

School of Education, University of Iceland (Iceland)

Email: bea30@hi.is

Ernest Yeboah

Science Department, Mount Mary College of Education - Somanya (Ghana) 